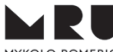
MYKOLO ROMERIO
UNIVERSITETAS Wrocławski
ISSN 1392-6195 (print) ISSN 2029-2058 (online) JURISPRUDENCIJA JURISPRUDENCE 2014, 21(1), p. 185-203.

\title{
ENERGY REGULATOR IN UKRAINE: LEGAL ASPECTS OF THE INDEPENDENCE IN THE LIGHT OF THE EU REQUIREMENTS
}

\author{
Yuliya Vashchenko \\ Taras Shevchenko National University of Kyiv, Faculty of Law, \\ Department of Administrative Law \\ Volodymyrska str. 64/13, 01601, Kyiv, Ukraine \\ Telephone: +380672 892649 \\ E-mail: y_vashchenko@univ.kiev.ua \\ Received on 9 February 2014, accepted on 13 March 2014 \\ doi:10.13165/JUR-14-21-1-09
}

\section{Introduction}

Energy sector is a strategic sphere of each country and one of the most important directions of cooperation between the EU and Ukraine. Ukraine is a fullfledged member of the Energy Community since February 1, 2011. The Protocol Concerning the Accession of Ukraine to the Treaty Establishing the Energy Community was signed on September 24, 2010 and ratified by Law of Ukraine № 2787-VI of $15.12 .2010^{1}$. Pursuant to Decision of the Ministerial Council of the Energy Community D/2011/02/MC-EnC of $06.10 .2011^{2}$, Ukraine shall bring into force the

1 Zakon Ukrainy "Pro ratyficaciju Protokolu pro pryjednannja Ukrainy do Dogovoru pro Zasnuvannja Energetychnogo Spivtovarystva”. Oficijnyj Visnyk Ukrainy. 2011, № 1.

2 Decision of the Ministerial Council of the Energy Community D/2011/02/MC-EnC: Decision of the implementation of Directive 2009/72/EC, Directive 2009/73/EC, Regulation (EC) № 714/2009 and Regulation (EC) № 715/2009 and amending Articles 11 and 59 of the Energy

Jurisprudencija/Jurisprudence

(C) Mykolo Romerio universitetas, 2014

(C) Mykolas Romeris University, 2014
ISSN 1392-6195 (print), ISSN 2029-2058 (online) http://www.mruni.eu/lt/mokslo_darbai/jurisprudencija/ http://www.mruni.eu/en/mokslo_darbai/jurisprudencija/ 
laws, regulations and administrative provisions necessary to comply with Directive 2009/72/EC, Directive 2009/73/EC that are included in the so-called "EU Third Energy Package". These Directives, in particular, prescribe the requirements on the legal status of national regulatory authorities in the spheres of electricity and natural gas, including the requirements on the independence of these bodies.

The energy regulator in Ukraine - the National Commission for State Energy Regulation (NERC) - was established in 1994 in accordance with the Presidential Decree № 738/94 of 08.12.1994. The NERC as a national natural monopolies regulatory commission was a central state executive body with the special status for a long time. At the present moment, there is a group of independent state regulatory bodies that are not included in the system of state executive bodies in Ukraine national commissions that conduct the state regulation in certain spheres. The NERC is a part of this group. However, despite the positive fact of the separation of national regulatory commissions, including the NERC, from the legislative, executive and judicial branches of power, the legal framework of these bodies in Ukraine needs to be enhanced in order to encourage the independence in the system of state bodies and fulfill the EU legislative requirements (in particular, concerning the independence of energy regulator).

Considering that the constitutional and administrative reforms are currently taking place in Ukraine, it is necessary to develop the recommendations aimed at the enhancement of the legislation on the legal status of regulatory commissions in Ukraine. Some problems of the constitutional status of the energy regulator in the context of the EU requirements were analyzed by the author in the previous publications ${ }^{3}$. This article focuses on the analysis of the EU requirements regarding the independence of the national regulatory authorities in the energy sector, latest researches on legal issues of the independence of regulatory authorities in general and the energy regulator in particular, the legal framework of the energy regulator in Ukraine and the development of the recommendations regarding the enhancement of the legislation of Ukraine aimed at the encouragement of the independence of the energy regulator in the system of state bodies of Ukraine.

\section{The independence of national energy regulators: general overview of the EU requirements}

It should be mentioned that the issues regarding the legal status of the independent regulatory authorities in general and the independence of energy

Community Treaty [interactive]. [accessed on 01-08-2013]. <http://www.energy-community. org/pls/portal/docs/1146182.PDF>.

3 Vashchenko, Y. National Regulatory Authorities in the Energy Sector of Ukraine: Problems of the Legal Status in the Context of the European Integration and the Administrative Reform. Jurisprudence. 2013, 20(3): 1231-1248. 
regulators in particular have been the subject of the researches of scholars from different countries ${ }^{4}$.

The researchers usually define the following three aspects of regulatory independence: the independence from the government, the independence from the regulated industries, and the independence in decision making.

Looking back to the development of the EU energy legislation, it should be noticed that the EU legislative requirements on institutional encouragement of energy regulation on the EU and nationals level were formed gradually. Therefore, the author proposes a brief review of the EU requirements on institutional aspects of energy regulation provided in the Directives of the first, the second and the third energy packages.

In the early 1990s, when liberalization of energy markets started in the EU, simultaneously with the beginning of the construction of the Internal Energy Market, the fundamental assumption was that competition should be widely introduced in the energy sector: "... Regulation was not considered a priority and the motto at that time was "as much competition as possible, as much regulation as necessary" (which meant no explicit regulation at all)." ${ }^{5}$

Directive 96/92/EC of the European Parliament and the Council of 19 December 1996 concerning common rules for the internal market in electricity ${ }^{6}$ and Directive 98/30/EC of the European Parliament and the Council of 22 June 1998 concerning common rules for the internal market in natural gas ${ }^{7}$ are the first Internal Energy Market Directives. The scholars present different opinions concerning the provisions of these Directives with regard to the aspects of energy regulation on the national level. In particular, some of them assume that national regulation was not contemplated in the first Internal Energy Market Directives ${ }^{8}$, whereas others pay attention to the fact that in the EU legislation on the common market for electricity, the crucial

4 Thatcher, M. Regulation after Delegation: Independent Regulatory Agencies in Europe. Journal of European Public Policy. 2002, 9(6): 954-972; Gilardi, F. Explaining Delegation to Independent Regulatory Agencies: The Role of Political Uncertainty [interactive]. [accessed on 14-08-2013]. $<$ http://onlinelibrary.wiley.com/doi/10.1002/j.1662-6370.2002.tb00336.x/pdf>; Hanretty, C.; Koop, C. De jure and de facto Independence of Regulatory Agencies. March 2010 [interactive]. [accessed on 14-08-2013]. <http://chrishanretty.co.uk/blog/wp-content/uploads/2010/03/ hanretty_koop_psa2010.pdf>.

5 Vasconcelos, J. Energy Regulation in Europe: Regulatory Policies and Politics of Regulation [interactive]. [accessed on 05-02-2014]. <http://www-55.mech.kuleuven.be/european-reviewof-energy-market/EREM_9-_Comment_Jorge_Vasconcelos.pdf $>$.

6 Directive 96/92/EC of the European Parliament and the Council of 19 December 1996 concerning common rules for the internal market in electricity [1996] OJ, L27/20.

7 Directive 98/30/EC of the European Parliament and the Council of 22 June 1998 concerning common rules for the internal market in natural gas [1998] OJ, L204.

8 Vasconcelos, J. Energy Regulation in Europe: Regulatory Policies and Politics of Regulation [interactive]. [accessed on 05-02-2014]. <http://www-55.mech.kuleuven.be/european-reviewof-energy-market/EREM_9-_Comment_Jorge_Vasconcelos.pdf >. 
requirement regarding the regulatory design is that the regulators must be independent of commercial interests in the sector $(96 / 92 / \mathrm{EC})^{9}$. As to the author's opinion, the first Internal Energy Market Directives do not impose on the Member States the strict obligation to establish (or to define) a special regulatory authority in the spheres of electricity and natural gas. However, some obligations of the Member States relating to the institutional aspects of energy regulation were defined by the Directives of the first energy package. Thus, pursuant to Article 20(3) of Directive 96/92/EC, the Member States shall designate a competent authority, which must be independent of the parties, to settle disputes relating to the contracts and negotiations in question. In particular, this authority must settle disputes concerning contracts, negotiations and refusal of access or refusal to purchase. In accordance with Article 21(2) of Directive 98/30/EC, the Member States shall designate a competent authority, which must be independent of the parties, to settle expeditiously disputes relating to the negotiations in question. In particular, this authority shall settle disputes concerning negotiations and refusal of access within the scope of this Directive. Pursuant to Articles 22 of both Directives mentioned above, the Member States shall create appropriate and efficient mechanisms for regulation, control and transparency so as to avoid any abuse of a dominant position, in particular to the detriment of consumers, and any predatory behavior. Preambles of both Directives stipulate that in accordance with the principle of subsidiarity, general principles providing for a framework must be established at Community level, but their detailed implementation should be left to the Member States, thus allowing each Member State to choose the regime, which corresponds best to its particular situation. Therefore, institutional aspects of regulation were referred to the competence of the Member States; however, the Directives prescribe the obligation of the Member States to encourage the independence of the competent authority responsible for the dispute settlements from the parties of a dispute. Considering that the quasi-judicial functions are usually defined as a part of functions of the independent regulatory authorities, their features, the provisions of the Directives mentioned above can be considered as the first steps on the way to the development of the EU requirements regarding the institutional aspects of energy regulation on the national level. Moreover, such provisions influenced the legal status of the energy regulators in some countries, where the regulators were established before the Directives from the first energy package came into force. For instance, in the Member States, like Denmark, where regulatory commissions have been built on corporatist representation, the market participants can no longer have seats in the regulatory commission ${ }^{10}$.

9 Johannsen, K.S. Regulatory Independence in Theory and Practice - A Survey of Independent Energy Regulators in Eight European Countries. AKF Forlaget. February 2003 [interactive]. [accessed on 05-02-2014]. <http://regulationbodyofknowledge.org/wp-content/uploads/ 2013/03/Johannsen_Regulatory_Independence_in.pdf $>$.

Ibid. 
However, the further experience demonstrated the necessity of establishment of common requirements on institutional aspects of national energy regulation. The Directives of the second energy package - Directive 2003/54/EC of the European Parliament and of the Council of 26 June 2003 concerning common rules for the internal market in electricity and repealing Directive 96/92/EC ${ }^{11}$ and Directive 2003/55/EC of the European Parliament and of the Council of 26 June 2003 concerning common rules for the internal market in natural gas and repealing Directive 98/30/ $\mathrm{EC}^{12}$ - include special requirements on the institutional encouragement of national energy regulation. The Directives (Article 23 of Directive 2003/54/EC and Article 25 of Directive 2003/55/EC) stipulate that the Member States shall designate one or more competent bodies with the function of regulatory authority. These authorities shall be wholly independent from the interests of the electricity (or gas) industry. They shall, through the application of this Article, at least be responsible for ensuring non-discrimination, effective competition and the efficient functioning of the market, in particular, through the functions defined by these Directives. Thus, the establishment of national regulatory authorities became compulsory in accordance with the Directives from the second energy package. However, the Member States had a right to establish one or several regulators. It should be mentioned that the Directives did not include the requirements on peculiarities of the legal status of such regulatory authorities (e.g., the establishment procedure, the rules on appointment and dismissal of managerial bodies, etc.). Therefore, these issues referred to the competence of the EU Member States. However, the Member States should have encouraged the independence of the regulatory authorities from the regulated industries.

While the Directives of the second energy package covered only one aspect of the independence - the independence from the regulated industries - the both aspects reflected in the Directives of the third energy package - Directive 2009/72/EC of the European Parliament and the Council of 13 July 2009 concerning common rules for the internal market in electricity and repealing Directive 2003/54/EC (Electricity Directive $)^{13}$ and Directive 2009/73/EC of the European Parliament and the Council of 13 July 2009 concerning common rules for the internal market in natural gas and repealing Directive 2003/55/EC (Gas Directive) ${ }^{14}$.

11 Directive 2003/54/EC of the European Parliament and of the Council of 26 June 2003 concerning common rules for the internal market in electricity and repealing Directive 96/92/ EC [2003] OJ, L176/37.

12 Directive 2003/55/EC of the European Parliament and of the Council of 26 June 2003 concerning common rules for the internal market in natural gas and repealing Directive 98/30/ EC [2003], OJ, L176/57.

13 Directive 2009/72/EC of the European Parliament and the Council of 13 July 2009 concerning common rules for the internal market in electricity and repealing Directive 2003/54/EC [2009] OJ, L211/55.

14 Directive 2009/73/EC of the European Parliament and the Council of 13 July 2009 concerning common rules for the internal market in natural gas and repealing Directive 2003/55/EC [2009] OJ, L211/94. 
As it was mentioned before, the Directives from the second energy package gave the Member States the right to define one or several regulatory authorities. In accordance with new Electricity and Gas Directives, the Member States shall designate a single national regulatory authority at the national level. Concerning this requirement, the European Commission explained that it is no longer possible for a Member State to designate at the national level one regulatory authority to deal with one of the regulatory duties listed in the Electricity and Gas Directives (or Regulations), say network tariffs, and a different (regulatory or other) authority to deal with another duty of the regulatory authority. It means that a single national regulatory authority at the national level must be entrusted with all regulatory duties provided for in the Electricity and Gas Directives. It is important to notice that the core duties of the national regulator can no longer be split between the regulator and the industrial Ministry ${ }^{15}$.

Pursuant to Article 35 of Directive 2009/72/EC and Article 39 of Directive 2009/73/EC, the Member States shall guarantee the independence of the regulatory authority and shall ensure that it exercises its powers impartially and transparently.

As to the independence from other state bodies, the Directives stipulate organizational and financial aspects of independence.

With regard to the organizational independence, the Member States shall ensure, in particular, that the regulator is legally distinct and functionally independent from any other public entity; its staff and the persons responsible for its management do not seek or take direct instructions from any government or other public entity when carrying out the regulatory tasks. The Member States shall ensure that the regulatory authority can take autonomous decisions, independently from any political body. However, the regulatory authority can cooperate, as appropriate, with other national state bodies, but not concerning the issues connected with its regulatory tasks defined by the Directives. As to cooperation of the regulatory authority with other state bodies, in particular, with the Government, competition authorities and regional regulators, the explanations of the European Commission shall be taken into consideration. For instance, the European Commission explains that, depending on the national constitution, it could be the government's competency to determine the policy framework, within which the regulator must operate. However, general energy policy guidelines issued by the government must not encroach on the regulator's independence and autonomy ${ }^{16}$.

15 Commission Staff Working Paper. Interpretative Note on Directive 2009/72/EC concerning common rules for the internal market in electricity and Directive 2009/73/EC concerning common rules for the internal market in natural gas. Brussels, 22 January 2010 [interactive]. [accessed on 14-08-2013]. <http://ec.europa.eu/energy/gas_electricity/interpretative_notes/ doc/implementation_notes/2010_01_21_the_regulatory_authorities.pdf $>$.

16 Commission Staff Working Paper. Interpretative Note on Directive 2009/72/EC concerning common rules for the internal market in electricity and Directive 2009/73/EC concerning 
The organizational aspect of the independence is also encouraged by the requirements for the appointment and the dismissal of the members of the board of the regulators or the top management. Thus, members of the board of the regulatory authority or, in the absence of a board, the regulatory authority's top management are appointed for a fixed term of five up to seven years, renewable once. The Member States shall also ensure an appropriate rotation scheme for the board or the top management. Concerning this provision, the European Commission explains that the maximum total term of members of the board of the NRA is two times seven years. However, the Member States can opt against the possibility for renewal, in which case the maximum term of office is seven years. Appointment will have to be made in accordance with the constitutional and administrative rules of the Member States ${ }^{17}$.

The members of the board (top management) may be relieved from office during their term only if they no longer fulfill the conditions set out in the Directives or have been guilty of misconduct under national law.

The Directives also stipulate the requirements on the financial autonomy of the regulators. Thus, the Member States shall ensure that the regulators have separate annual budget allocations, with autonomy in the implementation of the allocated budget, and adequate human and financial resources to carry out its duties.

As to the independence of the regulator from the regulated industries, the Directives prescribe that the Member States shall guarantee that the regulatory authority:

- $\quad$ is legally distinct and functionally independent from any private entity;

- $\quad$ ensures that its staff and the persons responsible for its management act independently from any market interest and do not seek or take direct instructions from any private entity when carrying out the regulatory tasks.

Considering that, Ukraine as a member of Energy Community shall guarantee the independence of its national regulatory authorities in the energy sector in accordance with the EU requirements, primarily the Electricity and Gas Directives of the third energy package mentioned above.

However, it should be noticed that the Directives mentioned above stipulate the main requirements on the independence of national regulatory authorities. The concrete methods of its implementation shall be defined by the authorized national authorities with consideration of the peculiarities of the national system of state bodies, as well as the level of legal culture and morality in the country. As to cultural issues, Johannsen, analyzing the issues of the regulatory independence of energy regulators in eight European Countries (Austria, Denmark, Greece, Ireland, Italy, Luxembourg, Northern Ireland and Spain), stressed that “...where the formal rules

common rules for the internal market in natural gas. Brussels, 22 January 2010 [interactive]. [accessed on 14-08-2013]. <http://ec.europa.eu/energy/gas_electricity/interpretative_notes/ doc/implementation_notes/2010_01_21_the_regulatory_authorities.pdf $>$.

Ibid. 
go bankrupt - informal rules, norms and cultural factors play an important role"18. Definitely, these issues are very important for each country. However, the adequate normative legal regulation, the effective institutional models of energy regulation are crucial for the countries in transit, such as Ukraine.

\section{The legal problems of the independence of the National Commission for Energy State Regulation (NERC)}

\subsection{The place of the NERC in the system of state bodies, its organizational legal form and relations with other state bodies}

Based on the theoretical approaches presented by scholars, two main aspects of the independence of regulatory authorities are considered for the purposes of this analysis:

1. The independence from other state bodies;

2. The independence from the regulated industry (industries).

The independence of the regulators from other state bodies includes the organizational independence, as well as the financial independence.

According to the author's opinion, the organizational independence can be encouraged, in particular, by:

- the statutory regulation of establishment, reorganization and liquidation procedures,

- the separation of the independent regulators from the traditional branches of power (legislative, executive and judicial),

- the establishment in a special organizational legal form (usually - a commission or an agency),

- the appointment of the managerial bodies by the several state bodies (or higher level officials) (e.g., by the Parliament and the Government, or by the Parliament and the President),

- the definition of the fixed term of office for the members of managerial bodes that should not be the same as the term of office of the subjects of appointment,

- the capable list of reasons for early relieving from office for the members of the board (top management),

- the autonomy in the regulatory decision-making.

Johannsen, K.S. Regulatory Independence in Theory and Practice - A Survey of Independent Energy Regulators in Eight European Countries. AKF Forlaget. February 2003 [interactive]. [accessed on 05-02-2014]. <http://regulationbodyofknowledge.org/wp-content/uploads/2013/ 03/Johannsen_Regulatory_Independence_in.pdf $>$. 
Pursuant to Article 11 of Law of Ukraine “On Electricity” № 575/97-BP of 16.10.1997 19 , the National Commission for Energy State Regulation is defined as a body of state regulation of the activity in the sphere of energy.

It should be mentioned that the constitutional and administrative reforms are currently taking place in Ukraine. At the present moment, there is a group of independent state bodies that are not included in the system of state executive bodies. The regulatory authorities in the energy sector - the National Energy Regulatory Commission and the National Communal Services Regulatory Commission - are part of this group ${ }^{20}$. Besides the energy regulator (NERC) and the communal services regulator, this group includes the National Commission for the State Regulation of Communications and Informatization, the National Securities and Stock Market Commission, the National Commission for the Financial Markets Sphere State Regulation.

The legal status of such bodies is currently regulated by laws of Ukraine and Presidential Degrees. For instance, the legal framework for the national natural monopolies regulatory commissions (including the NERC, the National Communal Services Regulatory Commission and the National Commission for the State Regulation of Communications and Informatization) is primarily stipulated by Law of Ukraine “On Natural Monopolies” № 1682-III of 20.04.2000²1, for the National Securities and Stock Market Commission - by Law of Ukraine "On State Regulation of the Securities Market in Ukraine” N448/96-BP of 30.10.1996 ${ }^{22}$, for the National Commission for the Financial Markets Sphere State Regulation - by Law of Ukraine "On Financial Services and State Regulation of Financial Services Markets" N2664III of 12.07.200 23 .

Thus, according to Article 11 of the Law "On Natural Monopolies", the national natural monopolies regulatory commissions are defined as collegial state bodies (not as central state collegial bodies, as it was defined earlier in Ukrainian legislation). These bodies also have a special procedure of establishment, reorganization and liquidation, as well as special rules for the appointment of managerial bodies and a special character of relations with other state bodies (which will be described later) that differ from the rules and procedures defined for the state executive bodies by the Constitution of Ukraine and laws of Ukraine. These legislative provisions prove

19 Zakon Ukrainy “Pro elektroenergetyku”. Oficijnyi Visnyk Ukrainy. 1997, № 46.

20 Vashchenko, Y. National Regulatory Authorities in the Energy Sector of Ukraine: Problems of the Legal Status in the Context of the European Integration and the Administrative Reform. Jurisprudence. 2013, 20(3): 1231-1248.

21 Zakon Ukrainy “Pro pryrodni monopolii”. Vidomosti Verhovnoi Rady Ukrai’ny. 2000, № 30.

22 Zakon Ukrainy "Pro dergavne regulyuvannia rynkiv zinnyh paperiv v Ukrai'ni". Vidomosti Verhovnoi Rady Ukrai’ny. 1996, № 51.

23 Zakon Ukrainy "Pro finansovi poslugy ta derzavne regulyuvannia rynkiv finansovych poslug". Vidomosti Verhovnoi Rady Ukrai’ny. 2002, № 1. 
the fact that the national natural monopolies regulatory commissions are separated from traditional branches of power - legislative, executive and judicial. However, it is necessary to include in the Constitution of Ukraine special provisions regarding the state collegial bodies/national regulatory commissions, in particular, concerning the organizational legal form and the establishment procedure of such bodies, the appointment and dismissal procedure for their members, the peculiarities of the relations of these bodies with the President of Ukraine, the Parliament of Ukraine, and the Government of Ukraine ${ }^{24}$. Considering the current constitutional and administrative reforms, it is necessary to develop the recommendations aimed at the enhancement of the legislation on the legal status of regulatory commissions in Ukraine with consideration of the EU requirements, latest researches on legal issues of the independence of regulatory authorities and analysis of the current legal framework of regulatory commissions in Ukraine.

One of the most important tasks is an introduction of such bodies as a new institution and the definition of their organizational legal form. Musa and Kopric, analyzing the legal problems of agentification in Croatia, warned that "Negative implications of careless introduction of the agency model, without recognizing it as a new institution, in the country that suffers from all the illnesses related to transition countries, can serve to other countries as an example of possible threats they should be aware of ${ }^{\prime 25}$. As it was mentioned above, the national natural monopolies regulatory commissions, as well as the National Securities and Stock Market Commission and the National Commission for the Financial Markets Sphere State Regulation, are defined as state collegial bodies by laws of Ukraine. However, we do not think that this category - a collegial state body - can be considered as a general title for this group of state bodies, as well as their organizational legal form. According to the doctrines of Constitutional and Administrative Law, two types of state bodies can be separated on basis of such classification criterion as the method of decision-making: sole state bodies and collegial state bodies. For instance, the Cabinet of Ministers of Ukraine is one of the state collegial bodies in Ukraine.

As it was mentioned by Deviatnikovaite and Bakaveckas, "Western scholars use a lot of terms in defining this type of institutions, i.e. QUANGO (quasi-autonomous nongovernmental organization), NDPB (non-departmental public body), EGO (extra-governmental organization), NGO (non-governmental organization), QAO (quasi-autonomous organizations), SAO (semi-autonomous organization). But the

24 Vashchenko, Y. National Regulatory Authorities in the Energy Sector of Ukraine: Problems of the Legal Status in the Context of the European Integration and the Administrative Reform. Jurisprudence. 2013, 20(3): 1231-1248.

25 Musa, A.; Kopric, I. What Kind of Agencification in Croatia? Trends and Future Directions. Transylvanian Review of Administrative Science. Special Issue: 33-53 [interactive]. [accessed on 08-02-2014]. <http://rtsa.ro/en/files/TRAS-35E-SI-4-MUSA,\%20KOPRIC.pdf>. 
most frequent term is IRA (independent regulatory agency)"26. Johannsen, analyzing the problems of accountability of energy regulators, used the term "commissiontype independent regulators"27. Thus, considering the international experience, the developments in Constitutional and Administrative Law Sciences, the author proposes to use the "independent regulatory authority" as a general title of such type of organizations, while the agencies and commissions - as widespread organizational legal forms.

However, Ukrainian legislative peculiarities should be considered in order to choose the general title and the organizational legal form (or forms) for these bodies. First of all, it should be mentioned that Ukrainian legislation includes the terms "the regulatory body" and "the body of the state regulation". According to Article 1 of Law of Ukraine "On Framework of the State Regulation in the Sphere of Economic Activity" N1160-IV of $11.09 .2003^{28}$, the regulatory body is defined as the Verkhovna Rada of Ukraine, the President of Ukraine, the Cabinet of Ministers of Ukraine, the National Bank of Ukraine, the National Council of Ukraine of Television and Broadcasting, the other state body, central state executive body, the Verkhovna Rada of the Autonomus Republic of Crimea, the Council of Ministers of the Autonomus Republic of Crimea, the local executive state body, the body of local self-government, as well as the official of any of the bodies mentioned above, provided that such a person has a right of sole adoption of regulatory acts in accordance with the legislation. The territorial bodies of central executive state bodies, state specialized institutions and organizations, noncommercial self-governmental organizations that conduct the management and governance of certain types of the compulsory state social insurance provided that these bodies, institutions and organizations adopt the regulatory acts according to their responsibilities are referred to the regulatory bodies. In general words, the main feature of the regulatory body is adoption of the regulatory act. Pursuant to Article 1 of the Law mentioned above, the regulatory act is defined as the normative legal act adopted by the authorized regulatory body that generally or partially aimed at the legal regulation of economic relations, as well as administrative relations between the regulatory bodies and other state bodies and subjects of economic activity. Additionally, the regulatory act is considered as an official document in written form adopted by the authorized regulatory body that establishes, changes or abolishes the

26 Deviatnikovaitė, I.; Bakaveckas, A. Independent Regulatory Agencies: Possibilities to Identify the Peculiarities of Their Activity and Their Position in the System of Lithuanian Public Administration Bodies. Societal Studies. 2009, 3(3): 333-349.

27 Johannsen, K.S. Regulatory Independence in Theory and Practice - A Survey of Independent Energy Regulators in Eight European Countries. AKF Forlaget. February 2003 [interactive]. [accessed on 05-02-2014]. <http://regulationbodyofknowledge.org/wp-content/uploads/2013/ 03/Johannsen_Regulatory_Independence_in.pdf $>$.

28 Zakon Ukrainy "Pro zasady dergavnoi regulyatornoi polityky v sferi gospodars'koi diyalnosti”. Vidomosti Verhovnoi Rady Ukrai’ny. 2004, № 9. 
legal norms, applies frequently and for undefined circle of persons, that generally or partially aimed at the legal regulation of economic relations, as well as administrative relations between the regulatory bodies or other state bodies and subjects of economic activity. Thus, the term "the regulatory body" is a general title for a wide circle of subjects that adopt legislative acts and other official documents aimed at the regulation of the economic activity. The Law mentioned above stipulates the special rules and procedures of the development, the adoption, the promulgation of the regulatory acts. The provisions of this Law apply to the regulatory acts of the national natural monopolies regulatory commissions, as well as of the National Securities and Stock Market Commission and the National Commission for the Financial Markets Sphere State Regulation (with some exceptions). Thus, these regulatory commissions can be considered as regulatory bodies in the meaning of the Law "On Framework of the State Regulation in the Sphere of Economic Activity" (in the context of the adoption of the regulatory acts). However, the term "the body of the state regulation" is applied to the regulatory commissions mentioned above (e.g., in the Law of Ukraine "On Electricity"). Therefore, it is thought that the "independent regulatory authority" is the most suitable general term for the regulatory commissions.

As to the organizational legal form, it should be considered that the term "agency" is used for the one of the organizational legal forms of the central state executive bodies according to the Ukrainian legislation, in particular, to Law of Ukraine "On Central State Executive Bodies" N3166-VI of 17.03.2011. Pursuant to Article 17 of this Law, the central state executive body is established as an agency if the majority of its functions referred to the functions of the management of the stateowned objects. The independent regulators (in particular, the energy regulator) have been established in the form of the commission since the early beginning.

Therefore, considering the international experience, the results of the researches devoted to legal issues of independent regulatory authorities, as well as the peculiarities of the Ukrainian legal regulation, the author proposes to use the title "independent regulatory authorities" as a general title of such state bodies and to define the "commission" as an organizational legal form of independent regulatory authorities.

Another important issue of the independence of the regulatory authority is its relations with other state bodies. As it was mentioned before, the energy regulatory authority can cooperate, as appropriate, with other national state bodies, but not concerning the issues connected with its regulatory tasks defined by Electricity and Gas Directives. However, the provisions of the Ukrainian legislation in this part are not clear. First of all, attention should be paid to the relations of the NERC as a national natural monopolies regulatory commission with the President of Ukraine, the Verkhovna Rada of Ukraine and the Cabinet of Ministers of Ukraine. In accordance with the Law of Ukraine "On Natural Monopolies", the national natural monopolies regulatory commissions are responsible to the President of Ukraine and accountable to the Verkhovna Rada of Ukraine. First of all, the regime of responsibility of the 
regulator to another state body is not in line with widespread understanding of the independence of the regulatory authority presented by scholars. Secondly, there are no special provisions regarding the content of the responsibility and accountability of the regulatory commissions in the laws. Some aspects of the accountability of the NERC can be found in the Regulation on the National Commission for the State Energy Regulation approved by Presidential Decree № 1059/2011 of 23.11.201129 (in accordance with the Law of Ukraine "On Natural Monopolies", commissions conduct their activity on the basis of the regulations approved by the President of Ukraine). Pursuant to paragraph 3(3) of such Regulation, the NERC submits to the President of Ukraine and to the Verkhovna Rada of Ukraine the annual report on the results of its activity and promulgates it on the web site of the NERC. First of all, according to the author's opinion, such provision should have been stipulated by the Law (not by the Presidential Decree). Secondly, there are no legislative provisions regarding the legal results of such reporting (e.g., regarding the responsibilities of the President of Ukraine and Verkhovna Rada of Ukraine with regards to the NERC's report). As to the relations of the regulatory commissions with the Government of Ukraine, there is only one provision in the Law of Ukraine "On Natural Monopolies" concerning this issue. In accordance with Article 11, the head of the national natural monopolies regulatory commission represents the interests of the commission in the Cabinet of Ministers of Ukraine and has a right to participate in the meetings of the Cabinet of Ministers of Ukraine with the right of advisory vote. At the same time, the Presidential Regulation on the NERC mentioned above stipulates that the NERC acts in accordance with the Constitution and the laws of Ukraine, acts and assignments of the President of Ukraine, acts of the Cabinet of Ministers of Ukraine, other normative legal acts, as well as this Regulation. Considering the statements mentioned above, the Ukrainian legislation needs to be enhanced in part of the regulation of the relations of the regulatory commissions (in particular, energy regulator) with other state bodies, primarily, with state bodies of the higher level, in order to guarantee the efficient independence of the energy regulator in conducting of its regulatory tasks and fulfill the EU requirements.

\subsection{The establishment and liquidation procedures of the NERC and the rules for the appointment and removal from office of its head and members}

The next important issue directly connected with the problem of the independence of the independent regulatory authorities in Ukraine is the establishment and liquidation procedure, as well as rules for appointment of managerial bodies.

29 Ukaz Presydenta Ukrai'ny "Pro Natzionalnu komisiju, shcho zdiisnyuje dergavne regulyuvannja u sferi energetyky”. Oficijnyj Visnyk Ukrainy. 2011, № 94. 
In particular, according to Article 11 of the Law of Ukraine "On Natural Monopolies", national natural monopolies regulatory commissions are established and liquidated by the President of Ukraine. The head and six members of the commission are appointed and relieved from office by the President of Ukraine by means of the approval of the relevant Decree. The head of the commission provides the President of Ukraine with the proposals regarding the candidates for the positions of the members of the commission. However, these provisions of the Law are not in correspondence with the Constitution of Ukraine. The Constitution of Ukraine includes capable list of the responsibilities of the President of Ukraine. As to responsibilities of establishment of state bodies, the President of Ukraine establishes, reorganizes and liquidates at the request of the Prime Minister of Ukraine the ministries and other central state executive bodies, courts pursuant to Article 106 of the Constitution of Ukraine. However, there are no responsibilities on establishment of state collegial bodies or national natural monopolies regulatory commissions, as well as responsibilities regarding the appointment and dismissal of its management and members, and approval of the regulations on such bodies. Therefore, the responsibilities of the President of Ukraine regarding the national regulatory authorities are stipulated by the laws of Ukraine, not by the Constitution of Ukraine ${ }^{30}$. Besides this constitutional problem, it should be considered that the sole responsibility of the President of Ukraine regarding the establishment and the liquidation of the independent regulatory authorities, as well as the appointment and liquidation of their managerial bodies, cannot encourage the required independence of these bodies. As evidently shown in the researches on the legal issues of the independence of the regulatory authorities, "To avoid a situation where the regulator takes instructions from the appointer in order to get reappointed, appointment procedures, which involve several parties (e.g. both parliament and government) and provisions against reappointment can be made." ${ }^{31}$ According to the author's opinion, the most appropriate way to solve this problem is to use the procedures of appointment and dismissal of the head and the members of the regulatory commissions similar to the procedures of appointment and dismissal of the Head of the National Bank of Ukraine and the member of the Council of the National Bank of Ukraine prescribed by the Constitution of Ukraine. Thus, the Head of the National Bank of Ukraine is appointed and relieved from office by the Parliament of Ukraine upon the submission of the President of Ukraine; one half of the members of the

30 Vashchenko, Y. National Regulatory Authorities in the Energy Sector of Ukraine: Problems of the Legal Status in the Context of the European Integration and the Administrative Reform. Jurisprudence. 2013, 20(3): 1231-1248.

31 Larsen, A.; Pedersen, L.H.; Sorensen, E.M.; Olsen, O.J. Independent Regulatory Authorities in Europe [interactive]. [accessed on 14-08-2013]. <http://sessa.eu.com/documents/wp/D73.1Larsen.pdf>. 
Council of the National Bank of Ukraine is appointed and relieved from office by the Parliament of Ukraine, another - by the President of Ukraine.

The provisions with regards to the term of office and the reasons for early relieving from office are very important for the independence of the regulator. In accordance with Article 11 of the Law of Ukraine "On Natural Monopolies", the head and the members of the commission are appointed for six years. One person can be the head and/or a member of the commission not more than two terms in succession. Thus, to the author's opinion, this provision allows members of the commission to have the total term more than two terms provided that it is not in succession. The author would like to pay attention to this formulation of the Ukrainian legislation. As it was mentioned before, the Electricity and Gas Directives of the third energy package define that the members of the board of the regulatory authority or, in the absence of a board, the regulatory authority's top management are appointed for a fixed term of five up to seven years, renewable once. According to the explanations provided by the European Commission, the maximum total term of the member of the board of the national regulatory authorities is two times seven years ${ }^{32}$. Thus, the total term can be less than but not more than two times seven years (fourteen years). Considering that, it is thought that the provision of the Ukrainian legislation regarding the term of office for the members of the regulatory commissions (at least concerning the energy regulator) needs to be put in accordance with the EU requirements.

As to the reasons of the early relieving from office, the Law of Ukraine "On Natural Monopolies" stipulates that the head, the member of the commission can be relieved from office in case of submission of the statement on removal, the inability to perform the obligations due to the health problems, coming into effect of the verdict of guilty in penal offence, existence of other reasons defined by laws. As it can be seen, the list of the reasons of the early removal from office of the head and the members of the national natural monopolies commissions is not capable to satisfy the general requirements for the independence of such bodies presented in the special scientific literature and is not in line with the EU requirements in part of the energy regulator. It should be considered that in accordance with the explanations provided by the European Commission the members of the board may be removed from office during their term only if they no longer fulfill the conditions set out in the Electricity and Gas Directives as regards their independence or they have been guilty of misconduct under national law. Although the Electricity and Gas Directives leave the room for the rules adopted at the national or regional level as far as misconduct is concerned, it has to be stressed that the possibility to remove a member of the board during

32 Commission Staff Working Paper. Interpretative Note on Directive 2009/72/EC concerning common rules for the internal market in electricity and Directive 2009/73/EC concerning common rules for the internal market in natural gas. Brussels, 22 January 2010 [interactive]. [accessed on 14-08-2013]. <http://ec.europa.eu/energy/gas_electricity/interpretative_notes/ doc/implementation_notes/2010_01_21_the_regulatory_authorities.pdf $>$. 
his or her term will apply in special cases only, such as fraud, bribery and breaches of the independence or impartiality of the NRA. The Member States will organize appropriate rights of defense for the persons concerned. Therefore, the provisions of the Ukrainian legislation concerning the reasons for the early removal from office of the head and members of the regulatory commissions need to be enhanced.

\section{Conclusions}

The energy regulator in Ukraine - the National Commission for the State Energy Regulation (NERC) - as a national natural monopolies regulatory commission is separated from the legislative, executive and judicial branches of power in Ukraine. Definitely, it is a very important step on the way of the encouragement of the independence of the regulator necessary for the efficient conduction of its activity and fulfillment of the EU legislative requirements stipulated by the Electricity and Gas Directives of the EU Third Energy Package. However, the Ukrainian legislation regarding the legal status of the regulatory commissions in general and the energy regulator in particular needs to be enhanced. Considering that the constitutional and administrative reforms are currently taking place in Ukraine, it is important to include relative provisions regarding the independent regulatory authorities in the Constitution of Ukraine, as well as to develop the special law of Ukraine on independent regulatory authorities in order to stipulate the main requirements for such types of state bodies. In particular, it is necessary to define the commission as an organizational legal form of independent regulatory authorities, to stipulate that the appointment and the removal from office of the heads and the members of such bodies is conducted jointly by the Parliament of Ukraine and by the President of Ukraine, to specify the peculiarities of the relations of the independent regulatory authorities with other state bodies, primarily with the state bodies and officials of the higher level.

\section{References}

Commission Staff Working Paper. Interpretative Note on Directive 2009/72/EC concerning common rules for the internal market in electricity and Directive 2009/73/EC concerning common rules for the internal market in natural gas. Brussels, 22 January 2010 [interactive]. [accessed on
14-08-2013]. <http://ec.europa.eu/ energy/gas_electricity/interpretative notes/doc/implementation_notes/ 2010_01_21_the_regulatory_authorities. pdf $>$.

Decision of the Ministerial Council of the Energy Community D/2011/02/MCEnC: Decision of the implementation 
of Directive 2009/72/EC, Directive 2009/73/EC, Regulation (EC) № $714 / 2009$ and Regulation (EC) № 715/2009 and amending Articles 11 and 59 of the Energy Community Treaty [interactive]. [accessed on 14-082013]. <http://www.energy- community. org/pls/portal/docs/1146182.PDF>.

Deviatnikovaite, I.; Bakaveckas, A. Independent Regulatory Agencies: Possibilities to Identify the Peculiarities of Their Activity and Their Position in the System of Lithuanian Public Administration Bodies. Societal Studies. 2009, 3(3): 333-349.

Directive 96/92/EC of the European Parliament and the Council of 19 December 1996 concerning common rules for the internal market in electricity [1996] OJ, L27/20.

Directive 98/30/EC of the European Parliament and the Council of 22 June 1998 concerning common rules for the internal market in natural gas [1998] OJ, L204.

Directive 2003/54/EC of the European Parliament and of the Council of 26 June 2003 concerning common rules for the internal market in electricity and repealing Directive 96/92/EC [2003] OJ, L176/37.

Directive 2003/55/EC of the European Parliament and of the Council of 26 June 2003 concerning common rules for the internal market in natural gas and repealing Directive 98/30/EC [2003], OJ, L176/57.

Directive 2009/72/EC of the European Parliament and the Council of 13 July 2009 concerning common rules for the internal market in electricity and repealing Directive 2003/54/EC [2009] OJ, L211/55.

Directive 2009/73/EC of the European Parliament and the Council of 13 July 2009 concerning common rules for the internal market in natural gas and repealing Directive 2003/55/EC [2009] OJ, L211/94.

Gilardi, F. Explaining Delegation to Independent Regulatory Agencies: The Role of Political Uncertainty [interactive]. [accessed on 14-082013]. <http://onlinelibrary.wiley. com/doi/10.1002/j.1662-6370.2002. tb00336.x/pdf>.

Hanretty, C.; Koop, C. De jure and de facto Independence of Regulatory Agencies. March 2010 [interactive]. [accessed on 14-08-2013]. <http:// chrishanretty.co.uk/blog/wp-content/ uploads/2010/03/hanretty_koop_ psa2010.pdf $>$.

Johannsen, K.S. Regulatory Independence in Theory and Practice - A Survey of Independent Energy Regulators in Eight European Countries. AKF Forlaget. February 2003 [interactive]. [accessed on 05-02-2014]. <http:// regulationbodyofknowledge.org/wpcontent/uploads/2013/03/Johannsen_ Regulatory_Independence_in.pdf $>$.

Larsen, A.; Pedersen, L.H.; Sorensen, E.M.; Olsen, O.J. Independent Regulatory Authorities in Europe [interactive]. [accessed on 14-08-2013]. <http:// sessa.eu.com/documents/wp/D73.1Larsen.pdf $>$.

Musa, A.; Kopric, I. What Kind of Agencification in Croatia? Trends and Future Directions. Transylvanian Review of Administrative Science. Special Issue: 33-53 [interactive]. 
[accessed on 08-02-2014]. <http:// rtsa.ro/en/files/TRAS-35E-SI-4MUSA,\%20KOPRIC.pdf>.

Thatcher, M. Regulation after Delegation: Independent Regulatory Agencies in Europe. Journal of European Public Policy. 2002, 9(6): 954-972.

Ukaz Presydenta Ukrai'ny "Pro Natzionalnu komisiju, shcho zdiisnyuje dergavne regulyuvannja u sferi energetyky". Oficijnyj Visnyk Ukrainy. 2011, № 94.

Vasconcelos, J. Energy Regulation in Europe: Regulatory Policies and Politics of Regulation [interactive]. [accessed on 05-02-2014]. <http://www-55. mech.kuleuven.be/european-reviewof-energy - market/EREM_9-_ Comment_Jorge_Vasconcelos.pdf $>$.

Vashchenko, Y. National Regulatory Authorities in the Energy Sector of Ukraine: Problems of the Legal Status in the Context of the European Integration and the Administrative Reform. Jurisprudence. 2013, 20(3): $1231-1248$.
Zakon Ukrainy "Pro ratyficaciju Protokolu pro pryjednannja Ukrainy do Dogovoru pro Zasnuvannja Energetychnogo Spivtovarystva”. Oficijnyj Visnyk Ukrainy. 2011, № 1.

Zakon Ukrainy "Pro elektroenergetyku". Oficijnyi Visnyk Ukrainy. 1997, № 46.

Zakon Ukrainy "Pro pryrodni monopolii". Vidomosti Verhovnoi Rady Ukrainy. 2000, № 30 .

Zakon Ukrainy "Pro dergavne regulyuvannia rynkiv zinnyh paperiv $\mathrm{v}$ Ukrai'ni”. Vidomosti Verhovnoi Rady Ukrai'ny. 1996, № 51.

Zakon Ukrainy "Pro finansovi poslugy ta derzavne regulyuvannia rynkiv finansovych poslug". Vidomost $i$ Verhovnoi Rady Ukrai’ny. 2002, № 1.

Zakon Ukrainy "Pro zasady dergavnoi regulyatornoi polityky $\mathrm{v}$ sferi gospodars'koi diyalnosti”. Vidomosti Verhovnoi Rady Ukrai'ny. 2004, № 9.

\title{
ENERGETIKOS REGULIUOTOJAS UKRAINOJE: TEISINIAI NEPRIKLAUSOMUMO ASPEKTAI ES REIKALAVIMŲ KONTEKSTE
}

\author{
Yuliya Vashchenko \\ Kijevo nacionalinis Taraso Ševčenkos universitetas, Ukraina
}

Anotacija. Straipsnyje analizuojami teisiniai Ukrainos energetikos reguliuotojo nepriklausomumo aspektai. Remdamasi ES ir Ukrainos teisés aktu analize, nepriklausomo reguliuotojo teisinio statuso tyrimais, autoré pateikia rekomendacijas, kaip Ukrainos teises aktais nustatyti adekvataus laipsnio Ukrainos energetikos reguliuotojo nepriklausomuma.

Reikšminiai žodžiai: energetikos reguliavimas, energetikos reguliuotojas, nacionaline reguliavimo institucija, nepriklausomos reguliavimo institucijos, administravimo reforma. 


\title{
ENERGY REGULATOR IN UKRAINE: LEGAL ASPECTS OF THE INDEPENDENCE IN THE LIGHT OF THE EU REQUIREMENTS
}

\author{
Yuliya Vashchenko
}

\section{Taras Shevchenko National University of Kyiv, Ukraine}

Summary. Energy sector is a strategic sphere of each country and one of the most important directions of cooperation between the EU and Ukraine. Ukraine is a full-fledged member of the Energy Community since February 1, 2011. The Protocol Concerning the Accession of Ukraine to the Treaty Establishing the Energy Community was signed on September 24, 2010 and ratified by Law of Ukraine № 2787-VI of 15.12.2010. Pursuant to Decision of the Ministerial Council of the Energy Community D/2011/02/MC-EnC of 06.10.2011, Ukraine shall bring into force the laws, regulations and administrative provisions necessary to comply with the legislative acts of the EU Third Energy Package, in particular, with Directive 2009/72/EC of the European Parliament and the Council of 13 July 2009 concerning common rules for the internal market in electricity and repealing Directive 2003/54/EC and Directive 2009/73/EC of the European Parliament and the Council of 13 July 2009 concerning common rules for the internal market in natural gas and repealing Directive 2003/55/EC. These Directives, inter alia, stipulate the requirements on the legal status of national regulatory authorities in the spheres of electricity and natural gas. Constitutional and administrative reforms are currently taking place in Ukraine. Therefore, the researchers, primarily, the representatives of Constitutional and Administrative Law sciences, shall provide the efficient solutions regarding the optimization of the system of state bodies. Based on the analysis of the EU legislation, the researches on the legal status of independent regulators and the legal framework for the energy regulator in Ukraine, the author provides recommendations on the enhancement of the legislation of Ukraine to encourage the adequate level of the independence of the Ukrainian energy regulator and fulfill the EU requirements. In particular, the author recommends the development of the special law on independent regulatory authorities, the appointment of the chairman and the members of the independent regulatory authorities jointly by the Parliament of Ukraine and by the President of Ukraine, the clear determination of the relations of the energy regulator with other state bodies.

Keywords: energy regulation, energy regulator, national regulatory authorities, independent regulatory authorities, administrative reform.

Yuliya Vashchenko, Kijevo nacionalinio Taraso Ševčenkos universiteto Teisès fakulteto Administracinès teisès katedros docentè. Mokslinių tyrimų kryptys: administracinè teisė, energetikos teisé, finansų teisè, žmogaus teisès.

Yuliya Vashchenko, Taras Shevchenko National University of Kyiv, Faculty of Law, Department of Administrative Law, Associate Professor. Research interests: administrative law, energy law, financial law, human rights law. 